\title{
EVOLUSI AKUNTANSI KEBERLANJUTAN
}

\section{Wulan Qur'Anie Aziza, Eko Ganis Sukoharsono}

Universitas Brawijaya, Malang, Indonesia

Email:wulanwqa@gmail.com, ekoganisub@ub.ac.id

\begin{abstract}
Abstrak
Studi ini bertujuan untuk membangun evolusi akuntansi keberlanjutan dari pemikiran awal hingga pemikiran abad ke-21. Metode studi yang digunakan adalah pendekatan kualitatif jenis riset kepustakaan. Dan perolehan topic studi 'Evolusi Akuntansi Keberlanjutan' membahas pemikiran pebisnis yang berbasis perspektif economic bottom line dan berangsur berubah menjadi triple bottom line, hingga kemudian disempurnakan lagi menuju paradigm pentuple bottom line. Paradigm pentuple bottom line yang terdiri dari lima aspek yaitu ekonomi (profit), social (people), lingkungan (planet), spiritualitas (phropet), fenoteknologi (phenotechnology) merupakan aspek-aspek yang membangun praktik akuntansi keberlanjutan. Penambahan dua aspek terakhir masih tergolong baru keberadaannya. Adanya penambahan dua aspek tersebut mampu mendorong organisasi dalam meningkatkan pencapaian pembangunan berkelanjutan secara berkomitmen. Penerapan praktik akuntansi keberlanjutan yang baik tidak dapat terlaksana tanpa adanya pelibatan profesi akuntan yang memiliki kualifikasi yang cukup dalam menangani isu dan strategi keberlanjutan organisasi. Selain itu laporan keberlanjutan yang komprehensif dan material sebagai wujud riil dari praktik akuntansi keberlanjutan tidak akan terwujud tanpa adanya peranan akuntan yang mempunyai kompetensi yang memadai. Pada akhirnya studi ini menghasilkan temuan evolusi akuntansi keberlanjutan yang dimulai dari terciptanya landasan awal tanggungjawab social lingkungan organisasi hingga penerapan dan kendala praktik akuntansi keberlanjutan di abad 21 atau era saat ini.
\end{abstract}

Kata Kunci: akuntansi keberlanjutan; pentuple bottom line; laporan keberlanjutan

\section{Abstract}

This study aims to build on the evolution of sustainability from early thinking to 21 st century thinking. The study method used is a qualitative approach to library research. And the topic of the study "Evolution of Sustainability Accounting" discusses the thinking of business people who are based on a bottom line economic perspective and gradually change to a triple bottom line, until it is refined again towards a pentuple bottom line paradigm. The pentuple bottom line paradigm which consists of five aspects, namely economy (profit), social (people), environment (planet), spirituality (phropet), phenotechnology (phenotechnology) are aspects that build sustainable accounting practices. The addition of the last two aspects is still relatively new. The addition of these two aspects is able to encourage organizations to increase the warning of sustainable development in a committed manner. The implementation of good sustainability accounting practices 
cannot be carried out without the involvement of the accounting profession who has sufficient qualifications in the problems and strategies of the organization's sustainability. In addition, a comprehensive and material sustainability report as a real form of sustainability accounting practice will not be realized without the responsibility of an accountant who has sufficient competence. In the end, this study produces findings on the evolution of sustainability starting from the initial foundation of environmental responsibility socialization organizations and sustainability accounting practices in the 21 st century or the current era.

Keywords: sustainability accounting; pentuple bottom line; sustainability report

Received: 2021-09-20; Accepted: 2021-10-05; Published: 2021-10-20

\section{Pendahuluan}

Dalam kehidupan sehari-hari manusia tidak lepas dari sebuah praktik akuntansi. Secara harfiah akuntansi memilik arti menghitung. Apabila memutar kembali waktu, praktik akuntansi/menghitung sudah dijalankan sejak zaman mesir kuno, bahkan di zaman Nabi Ibrahim AS, yang ditunjukkan dengan adanya pencatatan keuangan sederhana. Ini membuktikan bahwa awal keberadaan ilmu akuntansi sudah ada. Sayangnya pengakuan ilmu akuntansi ini masih redup alias samar-samar karena masih sedikit literatur yang mengulas lebih lanjut akan hal tersebut. Berlanjut pada abad 15, seorang biarawan Italia dengan keahliannya dibidang matematika yang bernama Luca Pacioli menerbitkan sebuah buku berjudul 'Summa de Arithmatica, Geometrika et Propertionalita'. Buku ini menjadi laris khususnya dikalangan para pebisnis lantaran materi yang didalamnya menjelaskan sistem pencatatan single entry yang dikembangkan menjadi sistem pencatatan double entry. Sistem pencatatan dalam akuntansi ini sangat berguna bagi pelaku bisnis agar seluruh aktivitas bisnisnya dapat terekam secara rinci. Kemunculan buku karangan Pacioli ini menjadi tanggapan sebagai asal mula akuntansi. Publikasi buku tersebut tidak hanya menjadikan pencatatan akuntansi diterapkan di Italia, namun ramai diterapkan di banyak negara. Hal ini menjadikan akuntansi mulai dipandang sebagai disiplin ilmu tersendiri. Akuntansi yang bermula sebagai alat untuk mencatat (record keeping) kemudia berangsur juga menjadi alat pelaporan bagi manajemen kepada pihak eksternal terkait pengelolaan organisasi (stewardship). Kenyataan tersebut mengawali hadirnya sub-kategori akuntansi yang disebut akuntansi keuangan.

Kehadiran sub-kategori akuntansi lainnya juga ditandai setelah revolusi industri Eropa pada abad 18-19 yang saat itu berakibat terjadinya integrasi antar organisasi karena transaksi perdagangan bebas perantara mekanisme pasar. Hal ini berakibat pada kinerja manajemen organisasi yang terganggu dalam perencanaan, pengelolaan, penilaian kinerja dan pengambilan keputusan. Akuntansi terdorong untuk membantu manajemen organisasi dalam mengendalikan proses manajemennya, sehingga dikembangkanlah akuntansi manajemen. Pengaruh revolusi industri juga menimbulkan kebutuhan informasi atas biaya produksi sehingga dikembangkan pula akuntansi biaya. Begitupun seterusnya berangsur angsur berbagai kebutuhan informasi yang relevan 
terutama dalam hal bisnis dibutuhkan sebagai acuan dalam penyelesaiannya. Ilmu akuntansi sebagai salah satu pengaruh besar dalam bisnis tidak luput mengembangkan ilmu akuntansi baru yang saat ini sudah terbagi dalam beberapa sub kategori seperti akuntansi pemerintahan, akuntansi perbankan, akuntansi perpajakan, akuntansi Internasional, akuntansi syariah dan sebagainya. Karena persoalan bisnis yang berbeda membutuhkan keperluan informasi akuntansi yang berbeda pula. Adanya sub kategori akuntansi yang berbeda-beda menjadikan aktivitas bisnis lebih terarah. Interaksi antara manajemen organisasi dengan pihak yang berkepentingan pun dapat terjalin dengan baik.

Namun dibalik itu semua fenomena alam telah berlalu lalang terjadi seperti perubahan iklim, hujan asam, pemanasan global, kerusakan lingkungan dan sebagainya. Fenomena yang terus terjadi ini juga tidak luput karena pengaruh perkembangan revolusi industri dan ulah manusia. Hal ini mendorong akuntansi berperan serta dalam melindungi bumi. Mengapa akuntansi dan bisnis harus ikut terjun menangani hal ini? karena ada sebuah tanggapan dimana akuntansi dan bisnis yang semakin dan akan terus berkembang pesat sehingga dianggap memiliki kedudukan penting dalam membantu negara agar lebih berkelanjutan. Oleh karenanya akuntansi mengembangkan sub kategori baru yaitu akuntansi sosial dan lingkungan.

Akuntansi social lingkungan adalah akuntansi yang tidak hanya untuk transaksi ekonomi, melainkan juga akuntansi untuk berbagai perkara social dan lingkungan (Gray, Owen and Adams, 1996). Akuntansi social lingkungan merupakan terobosan akuntansi yang mana di era global kebutuhan informasi organisasi tidak hanya berupa informasi keuangan saja, namun juga informasi non-keuangan seperti kinerja sosial lingkungan organisasi. Bahkan investor juga membutuhkan informasi non-keuangan organisasi sebagai penilaian resiko dan peluang organisasi di masa lalu, saat ini maupun masa mendatang. Adanya informasi non-keuangan mendukung pengambilan keputusan investasi dengan tepat sasaran. Selain itu kehadiran akuntansi social lingkungan juga merupakan penerang dalam mengubah pola pikir pelaku bisnis yang masih mengikuti pemikiran para ekonom klasik yang berpaku pada pendekatan kapitalis dimana orientasi bisnis mereka hanya tertuju pada peningkatan ekonomi saja atau hanya mengadopsi single/economic bottom line yang berfokus pada pembangunan manfaat ekonomi.

Seiring mulai diterapkannya akuntansi sosial lingkungan oleh para pelaku bisnis, pada perkembangannya akuntansi sosial lingkungan disebut akuntansi keberlanjutan (sustainability accounting). Hal ini tidak terlepas dari konsep pembangunan berkelanjutan (sustainable development) yang mana pembangunan negara tidak hanya menjadi kewajiban yang keseluruhannya dipikul oleh pemerintah, namun peran serta masyarakat juga dibutuhkan demi tercapainya kesejahteraan sosial dan kelestarian alam. keberlanjutan juga didukung untuk mengurangi tekanan stakeholder khususnya masyarakat atas keberadaan organisasi yang kebanyakan aktivitas operasionalnya membawa eksternalitas negatif terhadap mereka. Selain itu konsep akuntansi keberlanjutan juga sesuai dengan teori enterprise atas paradigma triple bottom line yang dicetuskan oleh john Elkington tahun 1997. Berdasarkan paradigma triple bottom line 
bisnis sejatinya harus berpaku pada tiga aspek yaitu aspek: ekonomi, sosial dan lingkungan.

Atas ini menjadikan akuntansi keberlanjutan telah banyak didukung dan diterapkan oleh para pelaku bisnis atau organisasi demi mendukung pembangunan yang terus berkelanjutan dalam ekonomi, sosial dan lingkungan. Akuntansi keberlanjutan menjadikan segala proses akuntansi dari pencatatan, pengukuran, pengakuan, pengungkapan, akuntanbilitas dan transparansi tidak hanya berfokus pada transaksi ekonomi namun juga peristiwa social dan peristiwa lingkungan yang mengitari transaksi ekonomi tersebut. Dalam pelaporan akuntansinya juga tidak hanya menunjukkan laporan tahunan atau laporan keuangan saja namun juga laporan keberlanjutan sebagai bukti atas kinerja sosial dan lingkungan organisasi. Tentunya laporan keberlanjutan harus dibuat berdasarkan standar pelaporan keberlanjutan. Beberapa standar pelaporan yang telah banyak diakomodasi diberbagai negara seperti GRI dan SASB.

Berlanjut pada tahun 2009, Sukoharsono dalam pidato pengukuhan guru besarnya menambahkan aspek baru sebagai penyempurna paradigma triple bottom line atau teori enterprise yakni aspek spiritualitas. Aspek spiritualitas dianggap mampu menhadirkan nilai penting dalam akuntansi keberlanjutan yang mana spiritualitas merupakan sisi kerohanian yang diawali dari hati yang mampu melandasi pebisnis sehingga meningkatkan kesadarannya terhadap tanggungjawab sosial lingkungan. Kemudian disusul tahun 2019, Sukoharsono kembali menambahkan aspek fenoteknologi sebagai penyempurna dari keempat aspek yang telah ada. Fenomena teknolongi muncul sebagai buah hasil revolusi industri dan atas ini sangat mendukung kemajuan era global dimana persaingan bisnis tentunya akan semakin ketat. Fenoteknologi dalam hal ini terkait dengan implementasi jaringan lunak, jaringan keras, telekomunikasi, basis data. Adanya aspek fenoteknologi tentunya akan membantu segala proses akuntansi terlebih akuntansi keberlanjutan.

Berpijak dari serangkaian peristiwa dalam evolusi akuntansi keberlanjutan, studi ini mencoba menunjukkan bahwa praktik akuntansi keberlanjutan selayaknya harus menjadi perhatian penting bagi pelaku bisnis dalam tanggungjawabnya terhadap seluruh pemangku kepentingan. Pergeseran sudut pandang bisnis dalam pencapaian pembangunan keberlanjutan menjadi penting untuk beberapa kondisi yang masih sering ditemukan seperti masih sedikit penerapan praktik akuntansi keberlanjutan oleh para pelaku bisnis secara sukarela, kurangnya pemahaman terhadap isu keberlanjutan, dan sebagainya. Ini dapat terjadi karena kurangnya faktor eksternal dan faktor internal yang mempengaruhi pelaku bisnis dalam penerapan tersebut. Dalam hal ini faktor eksternal berkaitan dengan tuntutan stakeholder dan kebijakan pemerintah terhadap organisasi. Faktor internal berkaitan dengan kesadaran dan kepedulian organisasi terhadap peristiwa social lingkungan disekitarnya. Keadaan ini menjadi salah satu tantangan tersendiri bagi para akuntan yang mana mereka harus membangun organisasi sesuai keinginan atasan juga menjalankan organisasi sesuai kebijakan pemerintah dan norma di masyarakat. 
Studi ini diharapkan dapat memberikan pemahaman lebih dalam mengenai evolusi akuntansi keberlanjutan dari pemikiran awal hingga pemikiran abad ked-21. Selain itu studi ini juga diharapkan dapat menjadi motivasi bagi organisasi agar menerapkan praktik akuntansi keberlanjutan secara komitmen.

\section{Metode Penelitian}

Penelitian ini menggunakan pendekatan metode penelitian kualitatif. Penelitian kualitatif digunakan untuk mengamati berbagai fenomena social berdasarkan perspektif penulis, sehingga dalam pengumpulan datanya tidak memanfaatkan model matematik ataupun alat pengukur statistik. Untuk itu dalam studi ini, dilkakukan analisis dan telaah terhadap 'Evolusi Akuntansi Keberlanjutan' yang dimulai dari yang dimulai dari terciptanya landasan awal tanggungjawab social lingkungan organisasi hingga penerapan dan kendala praktik akuntansi keberlanjutan di abad 21. Studi ini menggunakan jenis penelitian riset kepustakan yaitu penelitian dengan menggunakan teknik pengumpulan data dari sumber data yang relevan yang kemudian dilakukan pencatatan, penghimpunan atas catatan, penganalisisan untuk mengetahui keterkaitan antar temuan tersebut dan kelebihan dan kekurangan dari masing- masing temuan, dan menyimpulkan gagasan kritis dari hasil temuan yang telah analisis. Studi ini menggunakan data primer yang mana data primer ini diperoleh melalui sejumlah artikel, jurnal, website resmi dan beberapa penelitian sebelumnya oleh para ahli terkait. Tahap awal pegumpulan data dengan mengidentifikasi wacana yang berasal dari artikel, jurnal, website (internet) yang berkaitan dengan objek yang akan diteliti. Selanjutnya menghimpun seluruh data yang diperoleh dari berbagai sumber yang telah dipilih dan diidentfikasi. Setelah itu ditahap akhir menganalisis data-data tersebut untuk ditarik gagasan kritis yang relevan. Studi ini menggunakan teknik analisis data model Miles dan Huberman. Model analisis yang dapat digunakan dalam riset kepustakaan ialah analisis data model Miles dan Huberman. Model ini menerapkan bahwa kegaiatan analisis data perlu dilaksanakan secara interaktif dan terus menerus hingga penganalisisan data dirasa cukup. Kegiatan analisis data dalam model ini terdiri dari tiga kegiatan antara lain

1. Reduksi data

Mereduksi data sama artinya dengan merangkum, menyeleksi, membuang yang tidak perlu, dan memfokuskan hanya pada data-data yang dianggap penting. Reduksi data akan mempermudah dalam merumuskan dan memahami makna bacaan dengan lebih jelas dan memberikan efisiensi pada pengumpulan data berikutnya. Pada penelitian ini, data diperoleh melalui sejumlah data primer dan data sekunder yang relevan dengan objek penelitian, kemudian data tersebut dirangkum dan diseleksi sehingga mempermudah dalam perolehan makna bacaan dengan lebih jelas.

2. Penyajian data

Langkah selanjutnya adalah penyajian data agar data dapat terorganisir dan tertata dalam pola hubungan yang jelas sehingga akan mempermudah dalam 
memahami dan menarik kesimpulan. Penyajian data menurut Miles dan Huberman dapat dilakukan dalam bentuk uraian singkat, grafik, bagan, hubungan antar kategori dan sebagainya. Selain itu penggunaan teks yang berbentuk naratif juga dapat dilakukan untuk mempermudah pemahaman terhadap objek penelitian. Ketika tahap ini dilakukan, maka akan memudahkan dalam menaksir gagasan kritis pada objek penelitian dan dapat menarik kesimpulan dengan benar.

3. Kesimpulan/verifikasi

Selanjutnya yaitu menarik kesimpulan sebagai jawaban atas rumusan masalah penelitian. Penarikan kesimpulan harus dibuat dalam bentuk uraian singkat dan mengacu pada tujuan penelitian. Namun kesimpulan yang disajikan sifatnya masih sementara dan dapat berubah apabila tidak ada lagi bukti kuat yang ditemukan dalam mendukung pemgumpulan data selanjutnya. Kesimpulan yang diambil tetap harus terus diverifikasi selama penelitian berlangsung agar dapat dipertanggung jawabkan dengan benar.

\section{Hasil Dan Pembahasan}

\section{Perjalanan Perkembangan Akuntansi social dan Lingkungan}

Diawali oleh Howard Bowen seorang historian ekonom Amerika yang memberikan landasan awal mengenai tanggung jawab terhadap social dan lingkungan di tahun 1953. Bowen menghadirkan konsep tanggung jawab social lingkungan dalam bukunya yang berjudul "Social Responsibility of Businessmen", yang didalamnya menjelaskan kewajiban seorang pebisnis menyelaraskan tujuan bisnis organisasi dengan norma dan batasan yang berlaku di masyarakat. konssep yang dibangun Bowen mendapat banyak respon positif dari para pebisnis hingga banyak dari mereka menjadikannya sebagai dasar awal implementasi tanggung jawab organisasi terhadap social lingkungan meskipun konsep tersebut eksitensinya masih kurang bermakna kehadirannya di masa itu.

Dalam beberapa tahun, Keith Davis merespon konsep yanga dibangun Bowen dengan merumuskan persepsi lain dalam tulisannya "Can Business Afford to Ignore its Social Responsibilities?”. Didalamya menyimpulkan bahwa sesungguhnya tanggung jawab social organisasi diluar tanggung jawab ekonomi. Para pebisnis menanggapi persepsi Davis secara relevan, karena pada era 1960an pandangan terhadap tanggung jawab social organisasi masih membaur oleh pemikiran para ekonom klasik. Para ekonom klasik beranggapan bahwa tanggung jawab social seorang pebisnis hanya sebatas memaksimalkan penggunaan sumber daya seefisien mungkin sehingga dapat memproduksi barang atau jasa yang bisa pasarkan dengan harga yang dapat dijangkau masyakarat. Bila tugas tersebut dapat terlaksana dengan baik, maka organisasi disamping bisa meraih keuntungan penjualan, organisasi juga sudah melaksanakan tanggung jawab sosialnya.

Dalam satu decade kemudian tepatnya tahun 1971, Komite untuk Pengembangan Ekonomi Dewan Konferensi Amerika atau disingkat CED membuat sebuah pelaporan berjudul "Social Responsibilities of Business Corporations." yang 
publikasinya dijadikan sebagai kode etik bisnis karena adanya ungkapan bahwa tujuan dasar dari suatu bisnis adalah memberikan layanaan yang bermanfaat dalam memenuhi kebutuhan masyarakat. Didalam laporan tersebut terangkum tiga lingkaran konsetris yaitu:

a. Lingkaran tanggungjawab dalam

Organisasi bertanggungjawab dalam menerapkan kebijakan yang efektif untuk menumbuhkan ekonomi, memproduksi barang dan jasa, serta memperluas lapangan pekerjaan untuk masyarakat.

b. Lingkaran tanggung jawab tengah

Organisasi bertanggung jawab dalam menjalankan fungsi ekonomi disamping meningkatkan kepekaan terhadap nilai-nilai dan prioritas social mana yang harus diambil. Seperti meningkatkan interaksi dengan karyawan dan memperlakukan karyawan dengan adil di dalam organisasi.

c. Lingkaran tanggung jawab luar

Organisasi bisa kapan saja muncul seiring bertambahnya peran serta organisasi dalam meningkatkan kualitas lingkungan social.

Berlanjut pada tahun 1973, Keith Davis memperkuat persepsi sebelumnya dalam gagasan berjudul "Iron Law of Responsibility". didalamnya dikatakan bahwa adanya tanggung jawab social dari para pebisnis akan beriringan dengan otoritas social yang mereka miliki. Oleh sebab itu, apabila mereka menghirakukan tanggung jawab social tersebut, maka otoritas social organisasi yang mereka jalankan akan ikut merosot. Persepsi- persepsi yang dibangun Davis menjadikannya sebagai akar kemunculan atas identifikasi tanggung jawab pelaku bisnis hingga di era 1970-an memicu kemunculan konsep akuntansi social dan lingkungan. Selain itu statemen yang digagas oleh Davis menjadi landasan atas pentingnya legitimasi dan citra positif atas keberadaan organisasi.

Tahun 1980-an menjadi tahun yang cukup kritis dimana penerapan ekonomi sosialis mulai luntur dan disamut oleh penerapan ekonomi tradisinoal. Keadaan ini seiringan dengan sejumlah organisasi global yang perekonomiannya merosot secara tajam seperti General Motors dan International business machines. Dan ini menjadikan perkembangan akuntansi social lingkungan menjadi stagnan. Sejumlah organisasi yang masih aman merespon keadaan ini dengan pengaturan ulang strategi keuangan mereka dengan hati-hati. Sekalipun di era tersebut keadaan kurang memadai, perkembangan konsep akuntansi social lingkungan dan pelaporannya masih dapat berjalan. Hanya pada saat itu banyak muncul istilah baru seperti SRI atau Investasi Bertanggungjawab Sosial.

Setelah melalui beberapa periode perkembangan konsep akuntansi social lingkungan dan pelaporannya. Diawal tahun 90an mulai masuk model pelaporan akuntansi social lingkungan yang memanfaatkan balance scorecard atau kartu skor. Balance Scorecard pertama kali diperkenalkan oleh Art Schneiderman pada tahun 1987 dan kemudian didesain kembali oleh Kaplan dan Narton tahun 1990. Kaplan menganggap bahwa sistem balance scorecard saat itu kurang efektif sehingga 
Kaplan mengkombinasikannya dengan sistem pengukuran finansial dan nonfinansial agar organisasi tidak hanya berfokus pada ekonomi organisasi, namun juga perkara sosial. Empat perspektif balance scorecard atas misi dan strategi organisasi:

a. Keuangan: untuk mengetahui kontribusi dan pertimbangan ekonomi apa yang harus dilakukan agar dapat memaksimalkan laba.

b. Pelanggan: untuk mengidentifikasi sasaran pelanggan dan pangsa pasar mana organisasi akan bersaing dengan competitor.

c. Proses Bisnis Internal: untuk menilai segala aktivitas yang dikerjakan oleh karyawan maupun manajer agar dapat menentukan produk mana yang dapat memuaskan para pemegang saham dan sasaran pelanggan.

d. Pertumbuhan dan Pembelajaran: penyediaan prasarana sebagai pendukung tercapainya sasaran tujuan dari tiga perspektif lainnya.

Berlanjut ditahun 1990an hingga berjalan seterusnya perkembangan akuntansi social lingkungan semakin kompleks hingga praktik pelaksanaannya telah banyak dijalankan oleh pelaku bisnis atau organisasi diberbagai negara. Sejumlah ilmuan telah banyak merumuskan gagasan terkait konsep akuntansi social lingkungan termasuk Gray yang dalam publikasinya turut banyak mewarnai konsep akuntansi social lingkungan hingga mengiring pengembangan konsep tersebut dalam akuntansi keberlanjutan.

Akuntansi keberlanjutan (Sustainability Accounting) menurut polejewski (2011) dalam (Kusumawardani et al., 2018) adalah sistem akuntansi yang ditujukan untuk menarafkan strategi keberlanjutan. Akuntansi keberlanjutan juga merupakan perkembangan dari akuntansi social dan lingkungan dimana output pelaporannya berupa kinerja non-keuangan organisasi. Kinerja non-keuangan berkaitan dengan segala dampak langsung terhadap ekonomi, sosial dan lingkungan. Gray mengidentifikasi akuntansi keberlanjutan dalam tiga metode yaitu:

a. Biaya berkelanjutan: metode yang menggunakan penekanan biaya terhadap pengeluaran organisasi diakhir periode akuntansi agar mampu mengembalikan kualitas lingkungan hidup sebagaimana posisi mulanya.

b. Akuntansi persediaan modal alam: metode dimana terdapat kepedulian khusus yang dikerahkan pada keberadaan modal alam yang merupakan penyertaan yang selalu ada.

c. Analisis Input Output: metode pelaporan untuk produk dan barang sisa dalam unit yang dilihat dari arus fisik pemanfaatan material dan energy.

Dalam pelaksanaan praktik akuntansi keberlanjutan, organisasi dapat dikatakan bekerja pada keadaan dimana mengendalikan perekonomian yang terbatas, namun membutuhkan keadaan yang bisa menjalankan praktik bisnis yang akuntabel (Hifni, Sayudi and Hayat, 2020). Keberlanjutan dalam hal ini diartikan dengan memenuhi kebutuhan generasi sekarang namun tidak mempertaruhkan kebutuhan generasi mendatang. Hal ini tidak terlepas dari konsep pembangunan berkelanjutan (sustainable development) yang mana pembangunan negara tidak hanya menjadi kewajiban yang keseluruhannya dipikul oleh pemerintah, namun 
peran serta masyarakat juga dibutuhkan demi tercapainya kesejahteraan sosial dan kelestarian alam. Ketika konsep keberlanjutan telah dijiwai suatu organisasi maka segala strategi, kebijakan dan tindakan organisasi akan selalu mengandung prinsip keberlanjutan. Disamping itu prinsip keberlanjutan dapat terjadi apabila setiap strategi, kebijakan dan implementasi organisasi benar-benar dilakukan secara berkomitmen oleh segenap unsur atau pemangku kepentingan yang terlibat didalamnya (Kurnia et al., 2020). Komitmen tersebut dapat terwujud bila organisasi memiliki kesadaran tinggi yang mana bahwa mereka mempunyai tanggungjawab sosial lingkungan.

(Widjaja and Pratama, 2008) menuturkan bahwa ada tiga pokok pemahaman yang perlu menjadi kesadaran organisasi untuk menjalankan tanggung jawab social lingkungannya, diantaranya:

1. Organisasi selaku pihak berbadan hukum (artificial person) yang tidak berdiri sendiri, sehingga organisasi selain mempunyai tanggung jawab terhadap ekonomi juga social dan lingkungan

2. Pemegang saham bukan semata yang menentukan keberadaan (eksistensi) dan keberlangsungan (sustainabilitas) organisasi, namun pihak manapun yang berkepentingan dapat berperan serta dalam mentukan hal tersebut.

3. Melaksanakan tanggung jawab social dan lingkungan diartikan sebagai pengerjaan tugas yang sehari hari dilakukan oleh organisasi sebagai media untuk mendapatkan laba dari bisnis yang dikelola.

Meskipun saat ini telah banyak organisasi yang mulai menyadari akan pentingnya tanggung jawab social lingkungan, namun ada beberapa dari yang lain masih menunjukkan keberatan. Hal tersebut dikarenakan interaksi antara organisasi dengan social lingkungannya sifatnya non reciprocal dimana transaksi keduanya tidak menghasilkan prestasi yang timbal balik. Bahkan beberapa dari mereka yang sadar akan tanggung jawab social lingkungan masih mengalami kebingungan terhadap seberapa besar keterlibatan yang diberikan dalam menjalankan peran tanggung jawab social lingkungannya. Pada akhirnya dukungan pelaksanaan praktik akuntansi keberlanjutan dapat terkendali ketika organisasi memiliki pemahaman yang luas terkait isu keberlanjutan disamping kesadarannya akan tanggung jawab social lingkungannya.

\section{Triple Bottom Line Menuju Pentuple Bottom Line}

Akuntansi keberlanjutan memiliki sinergi atas penerapan teori enterprise yang diperkenalkan oleh John elkington pada tahun 1997 dalam bukunya yang berjudul "Cannibals With Forks, the Triple Bottom Line of 1st Century Business" dengan istilah yang disebut paradigm triple bottom line. Organisasi dikatakan dapat bekelanjutan bila memperhatikan ketiga aspek yaitu ekonomi (profit), social (people) dan lingkungan (planet) atau dikenal dengan sebutan '3P' Karena sinergi dari tiga aspek tersebut adalah kunci terjaminnya pembangunan berkelanjutan. Sehingga perluasannya sebagai berikut: bila organisasi ingin berlangsung dalam jangka waktu yang panjang (sustainable) maka keuangan (ekonomi) organisasi 
harus tetap stabil, operasional bisnis yang dijalankan sesuai harapan masyarakat (sosial) dan sekiranya menghindari atau meminimalisasi eksternalitas negatif yang ada sebagai akibat aktivitas operasional mereka terhadap lingkungan (lingkungan).

Berjalannya waktu pada tahun 2010, Sukoharsono dalam pidato pengukuhan guru besarnya menambahkan satu aspek penting yang dapat menyempurnakan paradigm triple bottom line yaitu aspek spiritualitas. Spiritualitas adalah sisi kerohanian yang dimulai dari hati sehingga dapat melandasi niat baik seseorang. Bila triple bottom line menjadi acuan pengukuran tanggung jawab sosial dan lingkungan, spritualitas berperan sebagai landasan dalam menentukan elemen apa saja dalam aspek ' $3 \mathrm{P}$ ' yang perlu dinilai. Karena kinerja: ekonomi, social dan lingkungan tidak akan terlaksana ketika tidak ada pendorong dalam diri pelaku bisnis untuk menjalankan ketiga aspek tersebut dengan baik. Bila aspek triple bottom line menaungi peran organisasi atas tanggungjawab sosial lingkungannya terhadap para stakheloder, aspek spiritualitas menaungi seluruh peran tanggung jawab organisasi yang nantinya dipertanggungjawabkan kepada tuhan.

Aspek spiritualitas menjadi penting untuk diakomodasi untuk meningkatkan kesadaran pelaku bisnis atas tanggungjawab sosial lingkungannya. Hal ini menjadi baik ketika pebisnis murni dan tulus melaksanakan kewajiban tersebut sebagai kesadaran bukan semata dorongan mengikuti tuntutan faktor eksternal seperti aturan pemerintah dan tuntutan stakeholder. Ketika organisasi menganut dimensi spiritualitas, maka kemungkinan komitmen untuk menjalankan tanggungjawab sosial lingkungan jauh lebih besar sehingga pencapaian pembangunan berkelanjutan dalam terus terlaksana. Selain itu akuntan yang menghadirkan nilai nilai spiritualitas dalam penyusunan laporan keuangan ataupun non-keuangan organisasi dapat memberikan dampak positif bagi keberlanjutan organisasi (Faiqoh and Mauludy, 2019).

Dalam pembentukan nilai-nilai spiritualitas, pebisnis atau organisasi dituntut untuk memiliki tanggung jawab terhadap peristiwa ekonomi, social dan lingkungan yang diintegrasikan dengan adanya 'holy spirit' (Sukoharsono, 2010). Holy Spirit adalah tatanan berlandaskan religiusitas dan universalitas. Holy spirit dalam tatanan religiusitas diartikan sebagai segala aktivitas yang mengacu pada unsur- unsur keagamaan. Tuhan telah menata seluruh tatanan yang ada dimuka bumi termasuk kehidupan manusia dan segala aktivitas perekonomiannya berdasarkan pada nilainilai agama. Sedangkan holy spirit dalam tatanan universalitas diartikan sebagai kasih yang tulus, cinta yang tulus, kesadaran transcendental serta dapat menjalankan kejujuran dan kontemplasi diri.

Berlanjut pada tahun 2019, (Sukoharsono, 2019) kembali menambahkan aspek tambahan yaitu fenoteknologi sebagai penyempurna dari keempat aspek yang telah ada. Fenoteknologi atau fenomena teknolongi muncul sebagai buah hasil revolusi industri dan kehadirannya sangat mendukung kemajuan era global dimana persaingan bisnis dimasa depan akan semakin rumit, siklus barang dan jasa semakin singkat, tuntutan stakeholder yang meningkat seiringnya waktu. Kurangnya 
dukungan teknologi menjadikan segala aktivitas lebih rentan terbengkalai dan efisien waktu yang sulit dicapai.

Fenoteknologi memberi pengaruh besar terhadap pemeliharaan kelangsungan hidup organisasi dalam berbagai sector termasuk akuntansi seperti akses data keuangan dan non keuangan berbasis komputer yang mempermudah dalam perolehan informasi yang lebih lengkap, relevan, terpercaya, dan pemanfaatan waktu yang efisien; akses informasi berbasis komputer lebih mudah dikelola, disimpan, dirubah ataupun dihapus; mempermudah akses pencarian informasi eksternal terbaru yang digunakan sebagai target penetapan strategi organisasi; peningkatan terbaru pada sistem akuntansi organisasi sehingga lebih mempermudah pengerjaan akuntan dalam segala prosesnya termasuk pengukuran, penyajian dan pengungkapan informasi keuangan, social dan lingkungan baik dalam laporan tahunan atau laporan keberlanjutan; penyediaan teknologi juga mendukung dalam pelaksanaan perbaikan kualitas lingkungan, penyediaan teknologi juga membantu organisasi meringankan tuntutan masyarakat dan pelanggan atas produk atau jasa yang ditawarkan. Fenoteknologi yang cukup lama telah ada, namun kehadirannya sebagai penyempurna dalam teori enterprise menjadikan praktik akutansi dalam akuntansi keberlanjutan menjadi semakin berkelanjutan dimasa depan.

Bermula dari paradigm triple bootm line yang didalamnya terdiri dari aspek: ekonomi, sosial dan lingkungan merupakan aspek-aspek yang dipertanggungjawabkan organisasi terhadap seluruh pemangku kepentingannya. Penambahan dua aspek baru yaitu aspek spiritualitas dan aspek fenoteknologi menjadikannya berubah menjadi paradigm pentuple bottom line. Dua aspek tambahan ini berperan dalam melandasi dan melingkupi kinerja ekonomi, social dan lingkungan pada triple bottom line sehingga keduanya tidak perlu ditanggungjawabkan organisasi kepada stakeholdernya, melainkan sebagai basis dalam pelaksanakan praktik akuntansi keberlanjutan organisasi.

Peralihan paradigm triple bottom line menjadi paradigm pentuple bottom line atau disebut '5P' menimbulkan pergeseran dalam menjalankan masing-masing misi aspek tersebut:

1. Aspek ekonomi (profit): Pastinya orientasi utama organisasi dalam membangun bisnisnya adalah untuk membangun manfaat ekonomi. Dalam setiap usaha pencapaian organisasi untuk memperoleh keuntungan harus tetap berlandaskan pada nilai spiritualitas.

2. Aspek sosial (people): dalam menjalankan aktivitas operasional organisasi disamping tujuannya untuk memperoleh keuntungan, organisasi terikat dalam kontrak sosial yang mana organisasi harus mampu memenuhi harapan masyarakat dan stakeholder terkait lainnya. Dalam menjalankan kontrak sosial tersebut, segala sesuatunya harus tetap berada dalam rambu rambu spiritualitas.

3. Aspek lingkungan (planet): dalam menjalankan aktivitas operasionalnya, pastinya organisasi akan memanfaatkan sumber daya yang ada dengan semaksimal mungkin dan penggunaan biaya untuk perolehan sumber daya yang 
seminimal mungkin. Salah satu sumber daya terbesar yang dimanfaatkan adalah kekayaan alam dan lingkungan untuk beroperasi. Kekayaan alam bisa habis dan rusak bila tidak dilestarikan. Sehingga dengan semestinya organisasi menjaga kelestarian alam dan tidak mengeksplitasi alam secara berlebihan. Tentunya semua aktivitas ini harus tetap disesuaikan pada nilai-nilai spiritualitas.

4. Aspek spiritualitas (prophet): aspek ini melandasi segala aktivitas dalam masing-masing aspek agar tetap berada dalam tindakan yang benar.

5. Aspek fenoteknologi (phenotechnology): aspek ini menjadi pengiring dan penyempurna dari keempat aspek yaitu ekonomi, sosial lingkungan dan spiritualitas.
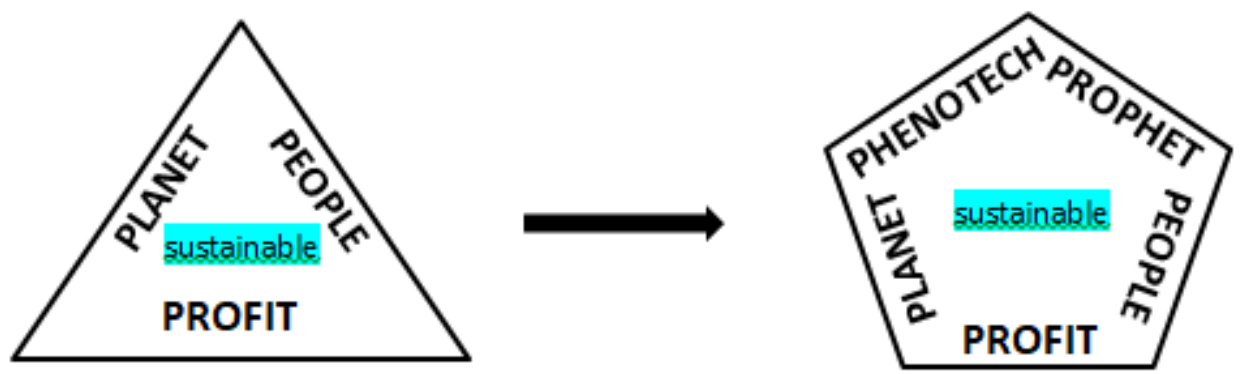

\section{Gambar 1}

\section{Triple Bottom Line dan Pentuple Bottom Line}

\section{Laporan Keberlanjutan Sebagai Wujud Pelaksanaan Akuntansi Keberlanjutan}

Laporan keberlanjutan adalah sebuah laporan yang dibuat oleh organisasi dalam hal pengungkapan (disclose) dan pengkomunikasian tanggungjawab sosial dan lingkungan dan tatakelola organisasi kepada para stakeholdernya (Kusniah and Lestari, 2019). Laporan keberlanjutan adalah wujud riil dari praktik akuntansi keberlanjutan yang mana pengungkapannya sebagai bentuk akuntabilitas organisasi terhadap seluruh stakeholdernya. Laporan keberlanjutan memuat seluruh informasi baik keuangan ataupun non-keuangan organisasi yang dapat menciptakan interaksi antara manajemen organisasi dengan para stakeholdernya. Kebanyakan dibeberapa negara masih menjadikan pelaporan keberlanjutan sebagai pelaporan sukarela (voluntary) yang masih jauh berbeda dengan laporan keuangan dan laporan tahunan yang sifatnya wajib (mandatory). Organisasi yang tergolong go-publik mungkin akan sukarela dalam pengadaan laporan keberlanjutan karena lebih banyak melakukan aktivitas secara global atau mungkin organisasi berskala besar yang mempunyai anak organisasi diberbagai wilayah bahkan lintas negara sebagai langkah pelaporan terpusat (Sudana, 2019).

Padahal laporan keberlanjutan memberi peluang legitimasi yang besar dari masyarakat atas keberadaan organisasi di lingkungan mereka. Laporan keberlanjutan juga dapat melegitimasi aktivitas operasional organisasi terhadap 
pemegang saham dan kreditur sehingga dapat menimbulkan insentif pelibatan keduanya dalam pelaporan organisasi (Mohamed Adnan, Hay and van Staden, 2018). Ada pula organisasi yang memperhitungkan terlebih dahulu biaya dan manfaat yang didapat, ketika manfaat yang didapat lebih besar dari biaya yang dikorbankan maka mereka akan sukarela melaksanakan dan melaporkan kinerja social lingkungannya. Selain itu alasan lain manajemen organisasi mendukung pengadaan laporan keberlanjutan yaitu untuk menjaga reputasi baik manajemen dan image atas merk organisasi. Alasan lainnya juga disebutkan (Shirish Sangle, 2010) bahwa manajemen organisasi cenderung akan melaporkan kinerja sosial lingkungannya ketika pesaing mereka pada industri yang sama banyak yang melaporkan kinerja sosial dan lingkungan. Keadaan ini mendukung peningkatan tren pelaporan keberlanjutan. Selain itu alasan utama yang paling banyak mendominasi dorongan organisasi dalam pengadaan laporan keberlanjutan adalah tuntutan dan tekanan stakeholder. Beberapa stakeholder utama yang memiliki pengaruh tinggi atas keberadaan dan kelangsungan organisasi seperti investor, pelanggan, masyarakat terkait lingkungan dan karyawan. Disamping itu ada pula organisasi yang mengadakan pelaporan keberlanjutan karena ketertarikan terhadap beberapa ajang penghargaan yang diadakan oleh sejumlah lembaga tertentu seperti NCSR (National Center for Sustainability Reporting) untuk mengapresiasi pelaku bisnis yang melaksanakan dan melaporkan tanggungjawab social lingkungan dengan baik.

Pada akhirnya di era global laporan keuangan dirasa kurang cukup dalam menilai kinerja organisasi secara keseluruhan. Awalnya nilai-nilai financial menjadi tolak ukur dalam mengukur kinerja dan prestai organisasi, namun saat ini beberapa faktor diperluas seiring bergesernya sudut pandang dalam berbisnis dan untuk menanggapi kuatnya tekanan stakeholder, sehingga menggiringlah pada konsep bisnis yang berkelanjutan (Kurniawan, 2017). Selain itu laporan keuangan dirasa masih kurang mencerminkan sifat informasi yang lebih komprehensif, material maupun transparan yang dibutuhkan oleh para stakeholder termasuk investor. (Kurniawan, 2017) menyatakan bahwa laporan keberlanjutan adalah akhir dari proses evolusi pelaporan organisasi yang mampu menilai kinerja organisasi secara komprehensif sehingga mempermudah dalam maksimalisasi pengambilan keputusan. Informasi didalamnya harus menampilkan kondisi organisasi sebenarnya yang juga melihat dari sudut pandang keberlanjutan. Laporan keberlanjutan harus menjadi dokumen strategik berkualitas tinggi yang informasinya bisa menempatkan risiko dan peluang yang ada untuk mencapai pembangunan berkelanjutan.

Pelaporan keberlanjutan juga tidak asal membuat, namun harus berdasarkan standar pelaporan keberlanjutan. Penggunaan standar pelaporan sangat penting agar susunan dan komponen atas kinerja sosial lingkungan berada dalam porsi yang tepat, lengkap dan relevan. Selain itu 'investor berkelanjutan' memerlukan suatu pedoman untuk mengintegrasikan strategi bisnis yang berkelanjutan dan ingin mengetahui apakah pilihan tersebut memberi dampak terhadap risiko dan peluang 
bagi keputusan investasi mereka. Hal ini juga didukung dari adanya kendala yang sering terjadi adalah banyak yang ingin mengungkapkan tanggung jawab social lingkungannya namun mengurungkannya karena mereka tidak mengetahui apa saja yang harus dimasukkan dalam laporan tersebut. Saat ini sudah ada sejumlah standar pelaporan global yang telah banyak diadopsi oleh para pelaku bisnis dalam melaporkan tanggung jawab social lingkungannya

\section{GRI (Global Reporting Initiative)}

GRI adalah sebuah badan yang didirikan tahun 1997 di Boston, Amerika Serikat yang membentuk sebuah pedoman laporan keberlanjutan untuk pertama kalinya yaitu tahun 2000. Tahun 2002 diterbitkan lagi GRI versi 2 atau dikodekan dengan GRI G2. Atas ini GRI telah dikukuhkan menjadi standard yang sebelumnya hanya pedoman. Secara berkala dalam waktu yang berurutan diluncurkan lagi GRI G3, GRI G3.1, dan yang terakhir GRI G4 yang merupakan standar terbaru yang dibentuk pada tahun 2013. Pembaharuan GRI secara berkala dilakukan untuk lebih memudahkan penyusunan laporan keberlanjutan atas informasi berharga yang kritikal dalam organisasi terkait keberlanjutan dan pada akhirnya mampu menghasilkan laporan keberlanjutan sedemikan rupa sebagai wujud praktik standar. Selain itu standar terakhir GRI G4 menjadikan lebih mudah diimplementasikan oleh pembuat laporan keberlanjutan organisasi baik mereka yang baru pertama kali menyusun atau mereka yang sudah fasih dalam menyusunnya.

\section{SASB (Sustainability Accounting Standard Board)}

SASB didirikan tahun 2011. Sejak tahun 2012, SASB secara bertahap membuat panduan pelaporan keberlanjutan yang melihat dari sector industry. Pedoman SASB secara relevan dan material memuat indicator kinerja spesifik sesuai karakteristik industrynya, sehingga hasil pelaporannya akan lebih seragam berdasarkan sector industry. Dan ini akan mempermudah ketika diperbandingan satu sama lain. Fokus utama dalam penggunaan standar pelaporan SASB adalah untuk memenuhi kebutuhan investor dengan memberikan pengungkapan laporan keberlanjutan yang material dengan kualitas tinggi. Salah satu alasan SASB lebih memprioritaskan kebutuhan investor karena investor mempunyai kebutuhan unik tersendiri yang berbeda dari kebutuhan stakeholder lain seperti pelanggan, pemasok maupun komunitas dan pelaporan berdasarkan standar SASB memang lebih ditujukan untuk memberikan kebutuhan unik terhadap khalayak yang berbeda.

\section{Peran Akuntan Dalam Menanggapi Praktik Akuntansi Keberlanjutan}

Keterkaitan Akuntansi dalam peran organisasi dalam menjalankan tanggungjawab sosial lingkungannya menjadi sebuah tugas unik bagi akuntan untuk menjalankan kinerja tersebut sesuai dengan harapan seluruh stakeholdernya. Dan ini menjadi sebuah tantangan tersendiri bagi akuntan sekaligus sinyal untuk mereka agar meningkatkan kompetensi yang dimiliki, karena di era global ini akuntan tidak hanya dituntut untuk menyusun dan melaporkan informasi 
keuangan saja, namun informasi non-keuangan pun menjadi tambahan informasi yang perlu disajikan. Informasi non-keuangan dimana terkait dengan tanggungjawab sosial lingkungan organisasi yang diproses dalam akuntansi keberlanjutan dan dilaporkan dalam laporan keberlanjutan pun tidak dapat dipisahkan (masih berkaitan) dengan laporan keuangan atau laporan tahunan organisasi.

Disamping itu hal ini sekaligus merupakan peluang bagi lulusan akuntansi kedepannya agar dapat memenuhi ekspetasi tersebut. Dan perlunya perhatian bagi perguruan tinggi maupun badan akuntansi agar dapat mencetak sosok akuntan yang mampu memenuhi harapan stakeholders dengan dibekali kompetensi yang lebih spesifik terkait praktik akuntansi keberlanjutan. Karena jika tugas ini tidak mampu dipikul oleh akuntan, maka kredibilitas pelaporannya bisa dipermasalahkan.

Oleh karena itu dalam banyak hal, seorang akuntan yang lolos sertifikasi CSRS (Certified Sustainability Reporting Specialist), dianggap mempunyai kualifikasi yang cukup dalam mendefinisikan dan mengetahui bagaimana pembangunan berkelanjutan diukur dan dilaporkan. CSRS adalah sertifikasi profesional pelaporan keberlanjutan yang diadakan sejak tahun 2007 oleh NCSR, dimana lulusan profesi CSRS diharapkan dapat memiliki kompetensi yang cukup sehingga mampu mempertanggungjawabkan seluruh informasi yang disampaikan dalam laporan keberlanjutan. Dilansir dalam https://www.ncsr-id.org bahwa, terakhir kali pada akhir tahun 2018 sudah tercatat sejumlah 1800 alumni profesi CSRS dalam lingkup Asia Tenggara. Angka ini terbilang masih sedikit karena dalam praktiknya, banyak akuntan yang kurang memahami sertifikasi CSRS dan secara personil kurang berorientasi ke arah profesi yang terspesialiasi dibidang tanggungjawab sosial dan lingkungan oleh organisasi (Wardani et al., 2017). Selain itu ada pula sertifikasi CSRA (Certified Sustainability Reporting Assurer) yang diadakan oleh NCSR tahun 2008 dengan harapan profesi akuntan mampu menilai keandalan dalam laporan keberlanjutan.

\section{Kesimpulan}

Perubahan sudut pandang bisnis dalam akuntansi yang diawali dari penerapan Economic bottom line menjadi triple bottom line, kemudian beralih menuju pentuple bottom line seharusnya menjadi cermatan seluruh pihak bahwa akuntansi termasuk disiplin ilmu yang juga berperan besar dalam menciptakan kehidupan yang baik. Perubahan sudut pandang bisnis yang digambarkan dalam penerapan paradigm menjadikan akuntansi memiliki aspek atau dimensi yang luas dalam pencapaian pembangunan keberlanjutan, tidak hanya keberlanjutan bagi organisasi atau pelaku bisnis namun juga keberlanjutan atas pembangunan nasional. Pencapaian ini dapat diwujudkan dalam penerapan praktik akuntansi keberlanjutan oleh organisasi. Bukti atas penerapan praktik akuntansi keberlanjutan tentunya menjadi penting dimata seluruh pemangku kepentingan organisasi. Bukti tersebut berupa pelaporan dalam laporan keberlanjutan. 
Ketika Laporan keberlanjutan menjadi penting dimata seluruh pemangku kepentingan organisasi, maka pelibatan pembuat laporan tersebut menjadi penting pula. Dalam hal ini, profesi akuntan yang memiliki kompetensi yang cukup dianggap mampu mengerjakan segala proses akuntansi baik pencatatan, pengukuran, pengungkapan, pengakuan, akuntanbilitas dan transparansi atas pelaporan tersebut. Profesi akuntan yang lulus sertifikasi CSRS diyakini cukup berkualifikasi dalam mengerjakan proses akuntansi dalam akuntansi keberlanjutan. Karena dalam penerapan praktik akuntansi keberlanjutan, akuntan harus mewujudkan pelaporan yang menarik dan jelas dihadapan seluruh pemangku kepentingan. Namun informasi dalam pelaporan keberlanjutan harus benar-benar menunjukkan kinerja keberlanjutan organisasi yang sebenarnya dengan standar pelaporan yang berlaku. Dari unggahan resmi NCSR, menunjukkan bahwa pada akhir tahun 2018 sudah ada sekitar 1800 alumi akuntan bersetifikat CSRS diwilayah Asia Tenggara. Angka ini masih terbilang sedikit meskipun praktik akuntansi keberlanjutan telah banyak diterapkan organisasi diberbagai negara.

Meskipun begitu studi ini meyakini bahwa dorongan organisasi dalam menjalankan praktik akuntansi keberlanjutan masih banyak dipengaruhi oleh faktor eksternal seperti tuntutan stakeholder, keinginan untuk memperoleh reputasi baik dimata stakeholder, keinginan untuk memperoleh ajang penghargaan dan masih banyak lagi. Salah satu alasan dari kondisi tersebut adalah kurangnya pengakomodasian nilai spiritualitas oleh pelaku bisnis. Ketika spiritualitas dan kesaran tertanam dalam diri pebisnis maka komitmen untuk menjalankan praktik akuntansi keberlanjutan dapat terus terjadi. Oleh karena itu pengakomodasian paradigm pentuple bottom line sangat penting dalam pelaksanaan praktik akuntansi keberlanjutan. Namun masih sedikit penerapan paradigm pentuple bottom terjadi karena penambahan dua aspek yaitu spiritualitas dan fenoteknologi masih terbilang baru dan beberapa literatur juga masih sedikit dalam mengulas terkait penambahan dua aspek tersebut. 


\section{BIBLIOGRAFI}

Faiqoh, S. And Mauludy, M. I. A. (2019) 'Penerapan Gri-G4 Sebagai Pedoman Baku Sistem Pelaporan Berkelanjutan Bagi Perusahaan Di Indonesia', Jurnal Akuntansi Universitas Jember. Doi: 10.19184/Jauj.V16i2.7260. Google Scholar

Gray, R., Owen, D. And Adams, C. (1996) Accounting And Accountability: Changes And Challenges In Corporate Social And Environmental Reporting, Prentice Hall. Google Scholar

Hifni, S., Sayudi, A. And Hayat, A. (2020) 'Sosio , Dan Ekonomik Sustainability Accounting Role: Accountability In Ecology, Socio , And Economy', Prosiding Seminar Nasional Lingkungan Lahan Basah, 4(April 2019), Pp. 404-414. Google Scholar

Kurnia, A. Et Al. (2020) 'Sustainable Development Dan Csr', Prosiding Penelitian Dan Pengabdian Kepada Masyarakat, 6(3), P. 231. Doi: 10.24198/Jppm.V6i3.26211. Google Scholar

Kurniawan, P. S. (2017a) 'Pemodelan Peta Materialitas Informasi Pada Laporan Keberlanjutan Perusahaan', Jurnal Riset Akuntansi Dan Bisnis Airlangga. Google Scholar

Kurniawan, P. S. (2017b) 'Profesi Certified Sustainability Reporting Specialist, Pelaporan Keberlanjutan, Dan Teori Enterprise (Suatu Tinjauan Mengenai Profesi Csrs Dalam Pelaporan Keberlanjutan)', Jurnal Ilmu Sosial Dan Humaniora, 6(1), P. 10. Doi: 10.23887/Jish-Undiksha.V6i1.9478. Google Scholar

Kusniah, S. And Lestari, Y. D. (2019) Sustainable Accounting Environmental Sebuah Tinjauan Fenomenologi. Bandung. Google Scholar

Kusumawardani, A. Et Al. (2018) 'Urgensi Penerapan Pendidikan Akuntasi Berbasis Akuntansi Sosial Dan Lingkungan', Ekuitas (Jurnal Ekonomi Dan Keuangan). Doi: 10.24034/J25485024.Y2018.V2.I1.3484. Google Scholar

Mohamed Adnan, S., Hay, D. And Van Staden, C. J. (2018) 'The Influence Of Culture And Corporate Governance On Corporate Social Responsibility Disclosure: A Cross Country Analysis', Journal Of Cleaner Production, 198, Pp. 820-832. Doi: 10.1016/J.Jclepro.2018.07.057. Google Scholar

Shirish Sangle (2010) 'Empirical Analysis Of Determinants Of Adoption Of Proactive Environmental Strategies In India', Business Strategy And The Environment, 19(July 2009), Pp. 51-63. Google Scholar

Sudana, I. P. (2019) 'Makna Penyusunan’, Pp. 115-134.

Sukoharsono, E. G. (2010) 'Metamorfosis Akuntansi Sosial Dan Lingkungan: 
Mengkonstruksi Akuntansi Sustainabilitas Berdimensi Spiritualitas'. Google Scholar

Sukoharsono, E. G. (2019) 'Sustaining A Sustainability Report By Modifying Triple Bottom Line To Pentaple Bottom Line: An Imaginary Research Dialogue', The International Journal Of Accounting And Business Society, 27(1), Pp. 119-127. Doi: 10.21776/Ub.Ijabs.2019.27.1.7. Google Scholar

Wardani, A. K. Et Al. (2017) 'Urgensi Akuntan Sosial Dan Lingkungan: Perspektif Institusional', Proceedings. Google Scholar

Widjaja, G. And Pratama, Y. A. (2008) Risiko Hukum \& Bisnis Perusahaan Tanpa Csr. Jakarta: Forum Sahabat. Google Scholar

\section{Copyright holder:}

Wulan Qur'Anie Aziza, Eko Ganis Sukoharsono (2021)

\section{First publication right:}

Syntax Literate: Jurnal Ilmiah Indonesia

This article is licensed under: 